Klementina Batina

DOI: https://dx.doi.org/10.21857/9xn31co6jy

Pregledni rad

Rukopis prihvaćen za tisak: 21.10.2020.

\title{
SURADNJA PUČKOG ETNOGRAFA IVE ČAKALIĆA I ODBORA ZA NARODNI ŽIVOT I OBIČAJE
}

\begin{abstract}
Sažetak
U radu se analizira sadržaj i vrijednost etnografskih i folklorističkih zapisa hrvatskog pučkog pjesnika i etnografa Ive Čakalića (1889. - 1971.), rodom iz Doljanovaca kraj Požege, u kontekstu njegove suradnje s akademikom Vinkom Žganecom i Akademijinim Etnološkim zavodom. Ivo Čakalić, iako slabije naobrazbe, volio je čitati i pisati te je velik dio svojega života posvetio zapisivanju starih narodnih običaja, poslovica i pučkih pjesama o čudesima i događajima iz života svetaca te o svakodnevnom životu. Budući da je surađivao s raznim stručnjacima i intelektualcima svojega vremena koji su ga poticali na bilježenje etnografske i folklorističke građe, ostao je sačuvan znatan dio njegovih zapisa. Rukopisna ostavština Ive Čakalića čuva se danas u raznim institucijama u Zagrebu, Požegi, Osijeku i Kaptolu te u privatnim zbirkama. U arhivu Odsjeka za etnologiju pohranjena je dvadeset i jedna rukopisna zbirka uglavnom zahvaljujući etnomuzikologu Vinku Žganecu. O tijeku te suradnje svjedoče korespondencija i fotografije koje je Žganec snimio tijekom terenskih istraživanja u Požegi i okolnim mjestima, a o vrijednosti i aktualnosti Čakalićevih zapisa činjenica da su svi rukopisi digitalizirani i objavljeni u Akademijinu digitalnom repozitoriju.
\end{abstract}

Ključne riječi: Ivo Čakalić; Doljanovci; etnografski zapisi; usmenoknjiževni zapisi; Vinko Žganec; Etnološki zavod HAZU.

\section{Etnološki projekt Jugoslavenske akademije znanosti i umjetnosti od 1888. do danas}

Etnološka praksa zapisivanja u sklopu Akademijine znanstvenoistraživačke djelatnosti započela je 1888. godine osnivanjem Odbora za sabiranje spomenika tradicionalne literature JAZU (danas: Hrvatska akademija znanosti i umjetnosti) koji je, kao prva etnološka institucija u Hrvatskoj, zacrtao smjer politike i prakse prikupljanja i objavljivanja građe o narodnom životu i običajima od osnivanja do danas (Primorac, 2010). Potaknut Pozivom za sabiranje hrvatskih narodnih pjesama koji je Matica hrvatska objavila 1877. godine, predsjednik Hrvatske akademije dr. Franjo Rački 1889. godi- 
ne održao je programatski govor $u$ kojemu je naglasio potrebu da se u okviru djelatnosti Hrvatske akademije izučava tradicionalna literatura južnoslavenskog naroda podrazumijevajući pritom prikupljanje usmenoknjiževne građe (pripovijetke, bajke, predaje, poslovice, zagonetke itd.) i domaćeg narodoslovlja temeljenog na opisima narodnog života, običaja i vjerovanja, odnosno sve one građe koju je moguće odrediti kao folklorističku, narodoslovnu, narodopisnu i etnoložku (Rački, 1889). Prvu uputu o prikupljanju takve građe za suradnike na terenu sastavio je Tomo Maretić i ona je objavljena 1895. godine kao samostalan poziv (Maretić, 1895) kako bi se čitatelje potaknulo na prikupljanje građe o narodnom životu, običajima i vjerovanjima te dijalektološkim prilozima s namjerom za objavljivanje u publikaciji Zbornik za narodni život i običaje Južnih Slavena (Vrbanić, 1896). U prvom svesku Zbornika objavljenom 1896. godine, osim uvodnog Pripomenka urednika Ivana Milčetića i zaključne rasprave s „bibliografijom slavenske folklore“ Antuna Radića, objavljeni su kraći prilozi raznih autora o životnim i gospodarskim običajima i vjerovanjima te folklornim tradicijama Hrvata, Crnogoraca, Bosanaca i Hercegovaca (Marković, 1897).

Iduće je godine u Zborniku objavljen opsežan i sveobuhvatan etnografski naputak za holističko opisivanje tradicijske kulture - Osnova za sabiranje i proučavanje građe o narodnom životu (dalje: Osnova). Osnovu je sastavio Antun Radić, a pitanja su strukturirana trodijelno, unutar dvanaest poglavlja koja daju smjernice za bilježenje svih aspekata materijalne i duhovne kulture. ${ }^{1}$ Radić je, u svojstvu novog urednika Zbornika, od svojih suradnika zahtijevao da „bude upravo onako zapisano, kako narod kaže“ te da zapisivač „,ne uzima nijedne riječi, koje narod u onom kraju ne pozna i ne razumije“ (Radić, 1897: 73,74). Smatrao je da objektivno i točno mogu opisivati samo oni koji poznaju i razumiju "narod“, a to su prvenstveno oni „koji su rođeni u narodu“ (pismeni seljaci, đaci, studenti), potom „stariji učitelji i svećenici“ te „druga gospoda" (činovnici, suci, odvjetnici, vlastela) od kojih se očekuje najmanje prinosa (Radić, 1897: 72, 73). Zahvaljujući etnološkom projektu Antuna Radića, koji je do 1902. godine uspostavio suradnju s brojnim zapisivačima, prikupljena je vrijedna rukopisna građa koja se i danas čuva u arhivu Odsjeka pod nazivom Stara zbirka te se kontinuirano istražuje i objavljuje. ${ }^{2}$

\footnotetext{
U Osnovi se obrađuju sljedeća poglavlja: 1. dio: I. Priroda, II. Tjelesni ustroj naroda, III. Jezik; 2. dio: IV. Životne potrepštine, V. Rad; 3. dio: Narodno srce: VI. Život, VII. Pravo, VIII. Običaji, IX. Zabave / Narodna duša: X. Poezija, XI. Vjerovanja / Narodna pamet (um): XII. Iskustvo, znanje, mudrovanje (usp.: Radić, 1897).

2 Tijekom Radićeva i Boranićeva razdoblja objavljene su dvije etnološke monografije s područja istočne Hrvatske koje su pisane prema Osnovi: Josip Lovretić: Otok. [Vinkovci]. ZNŽO (u 6 svezaka od 1897. do 1916.) i Luka Lukić: Varoš. ZNŽO (u 4 sveska od 1919. do 1926.). Djelatnici Odsjeka za etnologiju nastavili su u suradnji s Općinom Klakar s objavljivanjem opsežne Lukićeve građe. Kao posebno izdanje Hrvatske akademije i Općine Klakar objavljene su 2016. godine knjige: Klakarje: graditeljstvo, pokućstvo, sprave i oruđa početkom 20. stoljeća (dr. sc. M. Vuković, prir.) i Klakarje: pripovijetke i pjesme skupljane od sredine 19. do sredine 20. stoljeća (dr. sc. T. Perić-Polonijo i D. Vanić, prir.). Godine 2019., kao posebno
} 
Dragutin Boranić, koji je došao na mjesto Antuna Radića, tijekom svoje dugogodišnje funkcije na mjestu urednika Zbornika (1902. - 1955.) nastavio je suradnju s Radićevim zapisivačima, a u svrhu prikupljanja i objavljivanja novijih priloga poticao je i regrutirao i druge suradnike slijedeći Radićevu metodu zacrtanu u Osnovi. Nakon 1945. godine, u obnovljenom poslijeratnom Odboru, Boraniću se pridružuju i brojni vanjski suradnici s područja etnologije, etnomuzikologije, folkloristike i antropogeografije te se Zbornik otvara za obradu novih tema i istraživanja narodnog života, a pristigli rukopisi, koji uključuju rezultate terenskih istraživanja tradicijske kulture, postaju dio fonda Nove zbirke (od 1945. do danas). Godine 1951. dio fonda arhiva postaje i Zbirka Matice Hrvatske koja sadrži rukopise narodnih pjesama i druge građe te se smatra jednom od najvažnijih folklorističkih zbirki na području srednje i jugoistočne Europe. Djelatnici Odsjeka za etnologiju u suradnji sa znanstvenicima i stručnjacima s raznih područja nastavljaju s istraživanjem i multidisciplinarnom kritičkom obradom etnoloških i folklorističkih rukopisa koji se objavljuju u Akademijinoj publikaciji Zbornik za narodni život i običaje, Matičinoj biblioteci Hrvatske narodne pjesme (Rukopisna baština - Novi niz) te u posebnim izdanjima u suradnji s drugim institucijama i lokalnim zajednicama.

\section{Ivo Čakalić - pučki pjesnik i etnograf}

U jednoj od svojih rukopisnih bilježnica koje se čuvaju u arhivu Odsjeka Ivo Čakalić zabilježio je autobiografske podatke koji nam omogućavaju uvid u njegov život i djelomičnu rekonstrukciju njegova života. ${ }^{3}$ Iz rukopisa saznajemo da je rođen 19. ožujka 1889. u Doljanovcima kraj Požege (prilog 1). Osnovnu školu završio je u Kaptolu, mjestu koje je oko tri kilometra udaljeno od njegova rodnog sela (danas u sastavu Općine Kaptol). Iako slabije naobrazbe, volio je čitati i pisati te je, osim poljodjeljstvu, koje mu je bilo osnovno zanimanje, velik dio svojega života posvetio zapisivanju tradicijskih običaja, pučkih i nabožnih pjesama i molitava te druge usmenoknjiževne građe. Umro je 2. svibnja 1971. u 83. godini života. Osim osnovnih biografskih podataka, hrvatska leksikografija navodi Ivu Čakalića prvenstveno kao „hrvatskog pučkog pjesnika” koji je opjevao „čudesa i događaje iz života svetaca, a i svakodnevni život" (Zečević, 1993). Međutim, komparativna analiza Čakalićeve ru-

izdanje Hrvatske akademije i Hrvatskog sociološkog društva, objavljena je etnološko-sociološka monografija Selo u sjećanju - Petrijevci akademika Ivana Cifrića, a u rujnu 2020. godine etnološka monografija Župa Retkovci (1898. - 1902.) učitelja Ivana Filakovca koju je kao posebno izdanje Odsjeka i Centra za znanstveni rad HAZU u Vinkovcima priredila dr. sc. Anica Bilić. Unutar publikacije Zbornik za narodni život i običaji (br. 61), u rujnu 2020. godine, objavljen je i nastavak monografije o narodnom životu i običajima Klakarja učitelja Luke Lukića pod nazivom Opis sela Klakarja 1905. - 1953. (dr. sc. M. Vuković, prir.).

3 Usp.: Čakalić, Bilježnica starina I (NZ 124b), str. 89-94. 
kopisne ostavštine koja se čuva u arhivu Odsjeka za etnologiju pokazala je da je on, osim što je bio pučki pjesnik, bio i zapisivač usmenoknjiževnih tekstova te etnograf.

Ivo Čakalić rodio se u „,velikoj zadružnoj kući“, a kad su mu bile četiri godine, vratio se s majkom u njezinu rodnu kuću u selo Lukač zbog očeva "neuredna“ života. ${ }^{4}$ Kao dijete bio je boležljiv i slabije građe i zbog toga nije bio regrutiran u Prvi svjetski rat kao njegov brat. U školu je krenuo sa sedam godina te je završio pet godina osnovne škole i dvije godine opetovnice. Školu je rado pohađao i sve je znao „veoma dobro“ osim „računstva“, a na kraju godine redovito je dobivao nagrade. ${ }^{5}$ O sebi je istaknuo sljedeće: „Mogu Vam reći da sam ja od malih noguh jako volio knjigu i uvik zapisivati koješta pa kad sam u školu išo a kasnije kad sam bio čobanin uvik sam olovkom koješta zapisivao a i sliko pa tako i kasnije kad sam o zemlji radio... Rizbariju sam od ditinstva volio pa i do smrti volim rizbariti. ${ }^{\prime 6}$ Čakalićev likovni talent dolazi do izražaja u njegovim rukopisnim zbirkama, koje je sam ilustrirao, uvezivao i ukoričavao, a drvodjeljski talent u raznim uporabnim i ukrasnim predmetima i maketama koje je izrađivao, a danas se čuvaju u fundusu Gradskog muzeja u Požegi. Iz njegovih autobiografskih zapisa saznajemo i da se ženio dva puta - 1907. i ponovno 1911., nakon što mu je umrla prva supruga. Imao je dva sina, koja su umrla u mlađoj dobi od posljedica ranjavanja u Drugom svjetskom ratu. Svoju tugu za sinom Filipom opisuje u kontekstu ljubavi za narodnom pjesmom i plesom: „Pismu sam i kolo uvik volio dok sam bio mladić i neoženjen ali kad mi dojdoše brige ostavih ja kolo. Ali zapivat sam uvik volio osobito za plugom i kad je klanje svinja ili gdi u svati. Ali kad mi je dragi moj sinak Filip poginuo u ovom ratu više nisam nikad zapivo i glasa pustio od svitovni pisama. Jedino u crkvi i na prošte-

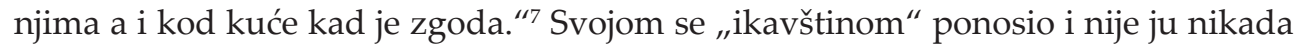
napustio, kao ni narodno ruho:

„Još u mladenačkoj dobi kad sam vidio da ima naših ikavskih knjiga vrlo sam ih želio čitati i imati pa i kupovati i tako da nemogu onaj 'e' niti 'je' izgovarati jer mi je to sve tudje prama mojem starinskom govoru. I kad čitam koju knjigu ja je uvik čitam čisto ikavski kao da nema " $\mathrm{e}$ ". Jer je to onaj naš pravi slavonski starinski govor. I eto kad pišem sve pišem ikavski i nitko mi nikad prigovorio nije...Ikavštinu je samo štampa izstisnula a naš narod i u govoru i u nošnji i u običajima svoje perje baca a tudjim se kiti...A stranu nošnju nebi htio na sebe metnuti za ništa."

Čakalić, Bilježnica starina I, NZ 124b, str. 89-94 


\section{Rukopisna ostavština Ive Čakalića u zbirci Odsjeka za etnologiju}

Rukopisna ostavština pučkog etnografa Ive Čakalića pohranjena je u raznim znanstvenoistraživačkim i baštinskim institucijama diljem Hrvatske te u privatnim zbirkama u Doljanovcima i Kaptolu. Najcjelovitiji i najopsežniji fond Ive Čakalića zastupljen je u Novoj zbirci Odsjeka za etnologiju i obuhvaća ukupno devetnaest rukopisnih zbirki te zbirku korespondencije (NZ 124a-š i NZ 116a-b). U rukopisne bilježnice manjeg formata zapisivač je tijekom šezdeset godina (1905. - 1963.) kontinuirano bilježio usmenoknjiževnu, pučku i etnografsku građu iz požeškoga kraja.

Bilježnica pod nazivom Pisme starinske divojačke u Požeškom kraju (NZ 124a) sadrži ukupno 274 zapisa kraćih usmenih pjesama te preko dvije stotine „kratkih pismica iz naroda" u dvostihu i četverostihu. Čakalić je pjesme zapisivao onako kako ih je čuo od svojih kazivačica, odnosno pjevačica (uz ponekog muškog kazivača) te je uz svaku pjesmu (osim nekoliko iznimki) zabilježio i podatak od koga ju je, gdje i kada čuo. Ponekad se radi o prikrivenom i grupnom ",autorstvu“, što je također zabilježio. ${ }^{8}$ Takav postupak odgovara naputku Matice hrvatske o sabiranju i vjernom bilježenju usmenih pjesama kako bi se zadovoljili kriteriji kritičkog objavljivanja u izdanju Hrvatske narodne pjesme. U naputku se od zapisivačā zahtijevalo da navedu podatke „tko ju je zabilježio, tko ju je kazivao ili pjevao, i gdje je zabilježena ili odakle je pjevač ili pjevačica, što su pjevali ili kazivali“ te kojoj vrsti pjesama pripada s obzirom na žanrovsku razdiobu na junačke, ženske i muhamedovske (Broz i Bosanac, 1896). Čakalić je u samom nazivu rukopisne zbirke pjesme odredio kao „starinske divojačke", odnosno ženske, te ih je na taj način žanrovski kvalificirao kao lirske (osmeračke) pjesme koje najčešće izvode (pjevaju) u kolu mlađe žene. Međutim, odrednica „starinske" podrazumijeva i stariji sloj dužih epsko-lirskih deseteračkih pjesama baladnog sadržaja koje su obično kazivale starije žene, ali te su pjesme u ovom rukopisu zabilježene fragmentarno. Pojedini motivi starijih pjesama upućuju na to da se radi o nekim od najljepših primjera zabilježenih usmenih epsko-lirskih pjesama baladnog karaktera (Šetala se ljuba Ivanova [pj. 15]; Kad se ženio Omer momče mlado [pj. 70]; Drum drumila lipa Mandalina [pj. 74]).

Na kraju rukopisne zbirke nalazi se sadržaj, odnosno popis svih pjesama po prvom stihu te broj stranice na kojoj je pjesma zapisana.

Sličnog je sadržaja i rukopisna zbirka Stare pisme i pismice (NZ 124e) u kojoj je zabilježeno 35 kraćih usmenih pjesama u osmeračkom i deseteračkom stihu te nekoliko pučkih pripovjednih pjesama u dvanaestercu. Zapaženo mjesto u tom rukopisu zauzimaju pjesme od dva stiha (bećarci) te od četiri stiha koje se pjevaju u kolu.

\footnotetext{
Ispod prve pjesme koja počinje stihovima Oj Požego varoš na vidiku, u teb Ivo izabrao diku zabilježio je: "Od osobe koja neće da joj se za ime znade“ (NZ 124a, str. 2), a ispod pjesme koja počinje stihovima Pod Budimom ovce plandovale, plandujući Budim potkopale (pj. 21) naveo je podatak: „Pivale Lukačke divojke oko god 1908.“ (NZ 124a, str. 18)
} 
Čakalić ih nije numerirao (ima ih preko četiri stotine!), ali je uz mnoge od njih bilježio kontekst izvedbe („piva soldatuša“, „rugaju se momci divojki“, "prkosi svekrvi cura“, "kaže čovik koji ima opaku ženu“ itd.).

Nekoliko rukopisnih pjesmarica sadrži zapise pučkih svjetovnih i nabožnih pjesama. Čakalićevo pučko pjesmotvorstvo najzapaženije je u deseteračkoj pjesmi Dragutin i Katica (NZ 124p) iz 1955. godine u kojoj je u 1.175 stihova opisao tragičnu ljubavnu priču. Svjetovne teme opjevane su i u deseteračkoj pjesmi Dila alkohola (NZ 124o), koju je Čakalić zapisao prema kazivanju mladića Tome Čenića iz Potočana o sukobu seljaka koji se zbio 1939. godine tijekom pokladnog kola u njegovu rodnom selu. U istoj rukopisnoj bilježnici nalazi se i druga Čenićeva pjesma Moja tuga, u kojoj je u deseteračkim stihovima opjevao svoje žalovanje za umrlom majkom i djevojkom koja ga je napustila anticipirajući s tim žalovanjem svoju preranu i iznenadnu smrt 1940. godine. Osmeračku pjesmu od 106 stihova pod nazivom Voćinska processia (NZ 124n) Čakalić je „,sastavio na slavu Drage gospe Voćinske god. 1967.“ na temelju svojih doživljaja i vjerskih promišljanja tijekom hodočašća. Taj je rukopis, zajedno s rukopisnim zbirkama Duhovne pisme od Blažene Divice Marie i druge pismice (NZ 124i) i Pisme iz čitanja i pripovidanja (NZ 124m) autor posredovanjem dr. Vinka Žganeca namijenio „Častnima Ocima Isusovcima u Zagrebu“, što saznajemo iz autorova pisma i Žganecove zabilješke. Iako su se te rukopisne zbirke neko vrijeme nalazile kod isusovaca, one su još uvijek dio arhiva Odsjeka. Rukopisna zbirka naslovljena Pisme složene iz legendah i iz pripovidanja od starih (NZ 124l), poput triju ranije navedenih, sadrži pučke pjesme različite metrike koje opisuju i veličaju život Majke Božje i Božjih svetaca te opisuju razna čudesa koja su se dogodila zahvaljujući nadnaravnim intervencijama, s jedinom razlikom što nisu oslikane svetačkim i drugim crtežima te lijepo ukoričene kao one namijenjene isusovcima. Autor je crteža Ivo Čakalić, a predloške i motive vjerojatno je, kao i za brojne pjesme, pronalazio u pučkim kalendarima, glasnicima i almanasima koji su mu bili dostupni tijekom perioda nastanka zapisa. U rukopisnoj bilježnici Starine, radovi i običaji, čudesa i svetišta i pričice (NZ 124f) Čakalić je u stihovima različite metrike opjevao i opisao događaje, ljude i običaje iz svakodnevnog života sela tijekom vremenskog perioda od pedeset godina te događaje iz života raznih svetica i svetaca. Za istraživače tradicijske kulture požeškoga kraja osobito su zanimljivi stihovani zapisi o ženidbenim i božićnim običajima, tradicijskim igrama, "dici i porodu“, „ženskim“ i "muškim“ radovima, diobi zadruga te raznim gospodarskim poslovima i običajima uključujući i opis tradicijskog načina spravljanju tijesta i pečenja kruha, a za istraživače Čakalićeva života zanimljivi su stihovani autobiografski zapisi Moji jadi. ${ }^{9}$

9 Usp.: Čakalić, NZ 124f: „Lokša i Oraški“ (str. 1-4, 371-374); „Moji jadi“ (str. 459-470). 
Rukopisna bilježnica naslovljena Starine u našem kraju (NZ 124h) sadrži stihovane opise tradicijske kulture i običaja koji su duža ili kraća varijanta zapisa iz prethodne bilježnice osim što su hagiografski dijelovi izostavljeni, a dodani crteži zapisivača (prilog 2) ${ }^{10} \mathrm{U}$ predgovoru tog rukopisa Čakalić je istaknuo kako je sve opisao (opjevao) onako kako je stvarno bilo u njegovu rodnom selu Doljanovcima i u susjednom selu Lukaču te kako su ga oduvijek zanimali starina i starinski poslovi:

„Ovdi ja ništa izmislio nisam ni u našim seljačkim radovima kano i u svim ovima običajima jer baš sve ovako je bilo u svima našim selima. Nije onda naš narod gospodski se hranio ni odivao ni gospodske namišćaje u sobama imo već bilo svo posve domaće i seljačko a i govor bio svud čisto starinski ikavski. A poslovi svakaki sve po seljački. A bi sada što dalje to gore sve se svud okreće po modi. A koji neću po novom onima kažu da su zaostali."

Čakalić, Starine u našem kraju, NZ 124h, str. 2

Čakalićevi etnografski zapisi nastali su sredinom 20. stoljeća, a nalaze su u pet rukopisnih bilježnica. Rukopis Svatovski običaji u starini (NZ 124j), osim ženidbenih običaja, sadrži i opise božićnih te korizmenih i uskrsnih običaja (prilog 3). Ponovljena, ali drugačije strukturirana i dopunjena građa nalazi se u rukopisu Običaji u Doljanovcima (Požeška kotlina) (NZ 116a) te u rukopisu Bilježnica starina I (NZ 124b), koji sadrži i opise starih tradicijskih igara i poslova te zapis o selu Doljanovci „, $\mathrm{u}$ prošlosti i sada“ u kojem Čakalić opisuje promjene koje su se dogodile u selu tijekom pedeset godina. Svoja zapažanja o promjenama u načinu života i običajima na selu istaknuo je u 78 crtica pod naslovom „Kako je bilo nekada. A kako je sada“. U tim se zapisima odražava Čakalićevo žaljenje za nekadašnjim načinom života:

"7. U staro doba su naše cure i snaše pa i starije žene na vratu djerdane i to što više struka pa kada bi igrale sve bi pozvekivali djerdani a danas idu sve golovrate kano i delije.

12. U staro doba kad dite se što malo pobolilo odma bake traže babe koje bajaju nad vodom i zivaju, sad toga više nema nego kad se dite što poboli odma lete $k$ doktoru. 32. U staro doba su pivali u kolu one lipe dugačke pisme da bilo milinje slušati. A danas o švalerima i druge kratke što se i ne pristaje za divojke.

40. U staro doba kad bi se udana ženska češljala ona bi se krila da ju muškarac ne vidi a ako muškarac naide ona bi se brže pokrivala. A eto danas sve i jesu gologlave."

Čakalić, Bilježnica starina I, NZ 124b, str. 81-88

10 Usp.: Čakalić, NZ 124h, 1. Svadbeni uzvanici oko stola (str. 44a); 2. Čauš ili Čajo ili Gospodin (str. 44b); 3. Mlatači mlate pšenicu (str. 116a); 4. Žene tuku župu (str. 123); 5. Barjaktar (str. 116b); 6. Selo Doljanovci u prošlosti i sada (str. 134a-b). 
Opsežan rukopis Opis starina (NZ 124d) nastao je na poticaj etnologinje Zdenke Lechner 1963. godine, a sadrži etnografske zapise, nekoliko crteža i pjesama te zapisivačevu autobiografiju. ${ }^{11}$ Zbirka Odgovori na pitanja o zadruzi (NZ 124s) sadrži tiskanu upitnicu o životu u zadruzi s upisanim odgovorima Ive Čakalića, vjerojatno iz istog razdoblja i pisanu na isti način kao i prethodna.

Raznovrsnu folklorističku građu Čakalić je zabilježio u tri rukopisa. U rukopisu Poslovice i praznovirice (NZ 116b) koje je skupljao u Doljanovcima u razdoblju 1950. - 1958. godine zabilježio je kratke jezične forme iz usmene komunikacije (poslovice, praznovjerice, izreke, zagonetke, dječje brojalice i pošalice). U Bilježnicu starina II (NZ 124c) zapisao je obilje poslovica abecednim redom, zagonetke, dječje brojalice, kratke pjesme u dva stiha (bećarce), nekoliko opisa starih tradicijskih igara te „Nike rečenice koje se čuju kod našeg naroda" (tumač manje poznatih riječi i izraza). U rukopisu Male pričice (NZ 124k) nalaze se ukupno 262 kraća opisa narodnog života, običaja, predaja i vjerovanja, odnosno raznih anegdota i kazivanja koja počinju rečenicama: „U staro doba..." ili „U stara vrimena...", a zastupljene su i pričice iz vremena i konteksta zapisa.

Čakalićeva Spomenica župe Kaptol (NZ 124g) sadrži kulturno-povijesnu građu (kroniku Župe Kaptol, popise stanovništva i zadruga) - uglavnom prijepise iz različitih izvora i publikacija, a Varia (NZ 124r) Čakalićeve opservacije i prijepise iz raznih izvora - opise inventara crkava, duhovne vježbe, naputke o liječenju bolesti, poslovice, molitve, "predskazivače vrimena“, rječnik, popis željezničkih stanica te dva kraća putopisa („Moje putovanje u Odvorce“ i „Moj četvrti put u Maria Bistri$\left.\mathrm{cu}^{\prime \prime}\right)$, zbog čega se stječe dojam da je ta rukopisna bilježnica Čakaliću služila kao molitvenik.

11 Sadržaj rukopisa NZ 124d: 1) Crtež („vratca na kijerima u našem Požeškom kraju...“, str. 1); 2) Autorov uvod: „Ovo sam ja sve svojom seljačkom i izmorenom rukom izpisao na zahtjiv Gospodjice prof. Zdenke Lechner u našem Slavonskom Gradu Osiku. Stari Ivo Čakalić, Doljanovci kraj Kaptola god. 1963.", str. 2); 3) "Svatovski običaji kod nas Šokaca u Požeškom kraju od Godine 1850 do Godine 1920" (str. 3-24); 4) "Običaji posli svatova“ (str. 24-26); 5) „Radovi u stara vrimena" (str. 27-28); 6) "Žetva“ (str. 29-34); 7) „Kako su naše žene pekle kruh“ (str. 35-36); 8) „Kako je bilo nekada a kako sada“ (str. 37-44); 9) "Župa“ (str. 45-46); 10) „Kako su naše žene tkale obojke“ (str. 47-48); 11) „O svom životu“ (str. 49-56); 12) „Šokačka divojka novijeg vrimena“<(crtež, str. 57-59); 13) „Mlad momak u šokačkoj nošnji“ (crtež, str. 58); 14) „Stare igre“ (str. 61-62); 15) „Perčin“ (str. 63-64); 16) „Prastarinske pisme” (str. 65-68); 17) „Klanje svinja“ (str. 69-72); 18) „Pastirski život“ (str. 73-80); 19) „Doljanovci u prošlosti i sada“ (str. 81-87); 20) „Kako su naše žene parile košulje“ (str. 88); 21) „Mlatači“ (str. 89); 22) „Božićni običaji“ (str. 91-96); 23) „Običaji posli Božića“ (str. 97-98); 24) „Poklade“ (str. 99-100); 25) „Korizma i Uskrsni običaji“ (str. 101-103); 26) „Kako su naše žene pravile taranu“ (str. 104-105); 27) „Prelje u zimi“ (str. 106); 28) „Snaša Šokica“ (crtež; str. 107); 29) „Kako su u staro doba pekli rakiju“ (str. 108); 30) „Kako su bili u staro doba Vašari“ (str. 109-110); 31) „Kako je diver nevu od zla oslobodio“ (pjesma, str. 111-112); 32) „Godovi časti ili kirvaji“ (str. 113-115); 33) „Kazalo“ (str. 117-118). 


\section{Suradnja Ive Čakalića i akademika Vinka Žganeca}

Suradnja Jugoslavenske akademije znanosti i umjetnosti i Ive Čakalića započela je zahvaljujući akademiku Vinku Žganecu, etnomuzikologu i dugogodišnjem članu i tajniku Odbora za narodni život i običaje. Žganec je u Odboru, u razdoblju nakon Drugog svjetskog rata, pokrenuo skupljanje i bilježenje tradicijskih napjeva i druge folklorističke građe te je uspostavio i razvijao suradnju s brojnim lokalnim kazivačima i istraživačima na terenu i s onim stručnjacima koji su sudjelovali u radu Odbora (Marković, 1977).

O profesionalnoj suradnji, ali i o prijateljstvu Vinka Žganeca i Ive Čakalića, svjedoči korespondencija pohranjena u Čakalićevoj rukopisnoj ostavštini (NZ 124š). Iz sadržaja prvog pisma koje je Žganec uputio Čakaliću (dat. u Zagrebu, 14/03/1966.) saznajemo da njihova korespondencija traje već dulje vrijeme te da je Čakalić nekoliko dana boravio u Zagrebu kod obitelji Žganec. O razlozima tog boravka Žganec ne piše, a vjerojatno se radilo o melografiranju tradicijskih napjeva. Žganec u pismu napominje da šalje i „praznu knjigu“ za bilježenje „raznih pjesama duhovnog sadržaja“ i "zgoda iz seljačkog života“ te nekoliko knjiga za čitanje. Također, potiče Čakalića da napiše nekoliko stranica vezano uz sintagmu „zli vjetar" te da mu napiše i pošalje svoj životopis s fotografijom. Iz sačuvanog pisma koje je Čakalić uputio Žganecu (dat. 24/02/1968) saznajemo da mu je pripremio za slanje „šest većih knjiga i 3 brošurice“ u kojima ništa nije izmislio već je napisao sve „baš kako je bilo“ te mu sa žaljenjem poručuje: „Nikad ja više Zagreba vidit neću jer sam i star i gluv. "U odgovoru na to pismo Žganec piše kako je dobio paket s knjigama i kako je pokrenuo postupak otkupa rukopisa. Drugo Čakalićevo pismo nije datirano te se čini da nije cjelovito. Na tom jednom sačuvanom listu Čakalić upućuje na važnost istraživanja i bilježenja razlika u mjesnim govorima: „Još bi jedno tribalo da naši književnici skupljaju naglasak po selima kako gdi zanašaju u govoru jer i to svud nestaje a ima toga različnoga." Uz korespondenciju su umetnuta i dva sumarna popisa rukopisa Ive Čakalića: 1) Rukopisi koje je Institut za narodnu umjetnost u Zagrebu 1970. g. otkupio od danas već pokojnog Ive Čakalića iz sela Doljanovci u Požeškoj kotlini (sign. 797-801) i 2) Rukopisi Ive Čakalića iz Doljanovaca u vlasništvu gosp. Franje Pipinića župnika um. Sl. Požega (1972.) koji je sastavio Josip Langhamer, tadašnji ravnatelj Gradskog muzeja Požega. Langhamer je popis sastavio na zamolbu Đuke Kuntarića, pravnika i publicista iz Požege, koji je nakon Čakalićeve smrti korespondirao sa Žganecom. O razlogu suradnje saznajemo iz Kuntarićeva pisma (dat. u Sl. Požegi/ 21/04/1972.) u kojem izvještava Žganeca o statusu Čakalićeve rukopisne ostavštine te mu šalje nekoliko priloga o Čakaliću koji su objavljeni u lokalnim tiskovinama. Također ga obavještava kako čuva i biografske podatke o Ivi Čakaliću koje je Čakalić osobno diktirao dr. Josipu Andriću i nekoliko pisama upućenih Andriću. 
Iako je Žganec marljivo prikupljao biografske podatke o Ivi Čakaliću i otkupio najveći dio njegove rukopisne ostavštine za Jugoslavensku akademiju znanosti i umjetnosti (ili JAZU) i za Institut za narodnu umjetnost ${ }^{12}$, nije poznat razlog zbog kojega ta opsežna i cjelovita građa nije nikada objavljena. Iz izvještaja o radu Odbora objavljenih u Ljetopisu saznajemo tek podatke o otkupu Čakalićevih rukopisa, a u poslovnoj korespondenciji nalazimo Žganecovu pozitivnu recenziju o Čakalićevu rukopisu Poslovice i praznovirice: „Čakalić je našem Odboru za NŽO poznat kao vrstan sakupljač i zapisivač narodnih pjesama, običaja, poslovica i dr. Jedan rukopis je od njega otkupljen već prije nekoliko godina, koji sadrži tekstove narodnih pjesama. On je sakupio i druge materijale iz toga područja (selo Doljanovci kod Slav. Požege), a materijal za ovaj rukopis je sakupljao i bilježio od 1950. do 1958. Njegovi se zapisi ističu time, što su pregledno svrstani u rukopisu. Npr. poslovice su poredane alfabetskim redom, pak se u njegovom mnoštvu materijala može brzo naći, što koga interesira, lako služi za dalju stručnu redakciju materijala." (ONŽO 26/67; dat. 30/04/1967.). Zahvaljujući akademiku Vinku Žganecu, ali i njegovim suradnicima iz Akademijina Odbora (Zdenka Lechner ${ }^{13}$, Josip Andrić1 ${ }^{14}$ ) i iz Požege (Josip Langhamer, Đuka Kuntarić) koji su prepoznali i poticali rad Ive Čakalića, sačuvan je vrijedan korpus zapisa tog iznimnog pučkog pjesnika i etnografa.

\section{Suradni projekt objedinjavanja rukopisne ostavštine Ive Čakalića}

Na inicijativu Odsjeka za etnologiju HAZU i ravnateljice Akademijine Knjižnice mr. sc. Vedrane Juričić ostvarena je suradnja s prof. dr. sc. Hrvojem Stančićem, koji je u sklopu redovne prakse studenata Katedre za arhivistiku i dokumentalistiku Odsjeka za informacijske znanosti Filozofskog fakulteta Sveučilišta u Zagrebu organizirao i s grupom studenata proveo digitalizaciju svih rukopisnih zbirki Ive Čakalića (ukupno 3.365 str.). Nakon digitalne obrade i unosa metapodataka, Čakalićevi su rukopisi i korespondencija objavljeni u Digitalnom repozitoriju Hrvatske akademije

12 Vinko Žganec bio je 1945. - 1948. kustos Etnografskoga muzeja u Zagrebu. U razdoblju 1948. - 1964. bio je znanstveni suradnik i ravnatelj Instituta za narodnu umjetnost u Zagrebu (danas: Institut za etnologiju i folkloristiku) koji je i osnovan na njegovu inicijativu. S obzirom na to da je od 1948. godine, kada je postao dopisni član JAZU, paralelno radio i djelovao i u Institutu i u Akademiji kao član i tajnik Odbora za narodni život i običaje (od 1966. kao redoviti član JAZU), vodio je brigu da arhivska građa koja je prikupljena na terenu bude arhivirana i dostupna u obje institucije.

13 Zdenka Lechner (1918. - 2017.) radila je kao etnologinja u Muzeju Slavonije u Osijeku (1951. - 1965.) te je tijekom tog razdoblja uspostavila mrežu svojih suradnika na terenu među kojima je bio i Ivo Čakalić. Nakon što je došla u Zagreb 1965. godine, radila je kao viša kustosica u Etnografskom muzeju te kao suradnica Odbora za narodni život i običaje JAZU (usp.: Petrović-Leš, 2017.).

14 Dr. Josip Andrić (1894. - 1967.) bio je folklorist, muzikolog, kompozitor, književnik. Surađivao je s akademikom Žganecom u Odboru za narodni život i običaje JAZU na istraživanju muzičkog folklora tijekom 50-ih godina 20. stoljeća u selima Bačke, na području Požeške kotline i Đakovštine te na o. Hvaru, o čemu je ostavio zabilješke i građu (NZ 87, 70, 33) (usp. Mihanović, 1983.). 
znanosti i umjetnosti http://dizbi.hazu.hr/ te su početkom 2016. godine postali javno dostupni korisnicima za pretraživanje i korištenje.

Digitalnu obradu i objavljivanje Čakalićeve ostavštine koja se čuva u arhivu Odsjeka za etnologiju inicirao je Tihomir Šmitpeter - učitelj, lokalni istraživač i predstavnik KUD-a „Ivo Čakalić“ iz Kaptola koji također posjeduje manji dio Čakalićeve ostavštine te se zalaže za njezino trajno očuvanje. Zajedničkom koordinacijom ostvareni su kontakti s institucijama u kojima se čuva Čakalićeva ostavština..$^{15} \mathrm{Od}$ početka inicijative (rujan 2014.) do danas digitalizirana je sva rukopisna ostavština Ive Čakalića. U dokumentaciji Instituta za etnologiju i folkloristiku u Zagrebu nalazi se pet rukopisa koji su pribavljeni otkupom 1970. godine. Rukopisi obasežu 1.385 stranica i objavljeni su u digitalnom repozitoriju Instituta. ${ }^{16}$ Rukopis Kraće priče iz Doljanovca (br. 797) sadrži kraće prozne zapise, Pjesmarica starinskih pjesama (br. 800) zapise usmenih pjesama, Rukopisni molitvenik (br. 798) prijepise molitvenih pjesama iz raznih tiskanih izvora, Pismarica duhovnih pisama (br. 799) zapise autorovih pučkih pjesama i drugih pjesama nabožnog karaktera prepisanih iz drugih izvora ili prema kazivanju, a rukopis Starine iz moga prastarog sela i našeg šokačkog kraja (br. 801) raznovrsnu etnološku i folklorističku građu skupljanu do 1970. godine. Zbirka Ive Čakalića u Gradskom muzeju Požega sadrži 153 inventirana predmeta - makete, fotografije, novinske članke, pisma, crteže, rukopise, popise i druga svjedočanstva o životu i djelovanju Ive Čakalića skupljene otkupom i donacijom iz raznih izvora. Rukopisna i tiskana građa obaseže ukupno 606 stranica i u cijelosti je digitalizirana. U Zbirci obiteljskih fotografija i dokumentacije Muzeja Slavonije nalazi se rukopisna bilježnica od 128 stranica iz 1963. godine koju je 1964. godine u muzejsku zbirku preuzela etnologinja Zdenka Lechner. Bilježnica sadrži etnološku i folklorističku građu te autobiografski zapis. Sačuvana je i njihova korespondencija te je tiskana upitnica o "pokljuki“ na koju je Čakalić zapisivao odgovore kao i tekst i crtež o "mlatačima“. Tihomir Šmitpeter objedinio je rukopisnu građu Ive Čakalića koja se nalazila u Općini Kaptol, Župi sv. Petra i Pavla Apostola u Kaptolu i u njegovoj privatnoj ostavštini te ju je u cijelosti digitalizirao. Radi se o ukupno 862 stranice zapisa usmenih i pučkih pjesama, molitava i običaja te raznih bilješki i izrezaka iz tiskovina koje će nakon metapodatkovne obrade biti implementirane na internetskoj stranici Općine Kaptol.

\footnotetext{
15 Na inicijativu Tihomira Šmitpetera, projekt digitalizacije i objedinjavanja Čakalićeve ostavštine podržali su Općina Kaptol (načelnik Mile Pavičić), Župa sv. Petra i Pavla Apostola u Kaptolu (župnik Josip Klarić), KUD „Ivo Čakalić“ Kaptol (predsjednik Damir Poljanac), HKD „Tkanica“ Alilovci (predsjednica Elvira Miletić), Gradski muzej Požega (voditeljica Zbirke Ive Čakalića Maja Žebčević Matić), Muzej Slavonije Osijek (etnologinja Ana Wild) i Institut za etnologiju i folkloristiku u Zagrebu (dr. sc. Koraljka Kuzman Šlogar).

16 Usp.: https://repozitorij.dief.eu/a/.
} 


\section{Umjesto zaključka}

Pučki pjesnik i etnograf Ivo Čakalić ostavio je bogat korpus rukopisne građe na ikavskom govoru koja se u izvornom obliku čuva u raznim institucijama u Zagrebu (Odsjek za etnologiju Hrvatske akademije znanosti i umjetnosti, Institut za etnologiju i folkloristiku), Požegi (Gradski muzej Požega), Osijeku (Etnografski odjel Gradskog muzeja), Kaptolu (Župa sv. Petra i Pavla Apostola) i u privatnim ostavštinama. Odsjek za etnologiju Hrvatske akademije znanosti i umjetnosti podržao je inicijativu i suradni projekt kojim se planira objedinjavanje digitalizirane građe Ive Čakalića (ukupno 6.348 stranica!) na način da se uspostavi jedinstvena internetska stranica koja će omogućiti pregled dislocirane građe. Tek nakon uvida u cjelokupnu ostavštinu Ive Čakalića moći će se pristupiti sustavnijem komparativnom istraživanju etnografskih i folklorističkih zapisa i kulturno-povijesne građe iz sela i mjesta s područja Župe Kaptol u kontekstu proučavanja tradicijske kulture požeško-slavonskog kraja. Ti su zapisi važni za sva znanstvena i stručna istraživanja na području hrvatske etnologije, folkloristike, etnomuzikologije i etnolingvistike, ali i svima onima koji se bave kulturnom povijesti lokalne i šire zajednice, pogotovo baštinskim i odgojno-obrazovnim institucijama koje educiraju i komuniciraju baštinske poruke preko različitih medija.

\section{Izvori i literatura}

Broz, Ivan i Stjepan Bosanac (1896), Hrvatske narodne pjesme, knjiga proa. Junačke pjesme. Zagreb: Matica hrvatska, str. XX.

Čakalić, Ivo (1949), Običaji u Doljanovcima (Požeška kotlina), rkp. OE HAZU NZ 116a, 72 str.

Čakalić, Ivo (1950-1958), Poslovice i praznovirice, rkp. OE HAZU NZ 116b, 124 str.

Čakalić, Ivo (1906-1955), Pisme starinske divojačke u Požeškom kraju, rkp. OE HAZU NZ 124a, 316 str.

Čakalić, Ivo (1905-1956), Bilježnica starina I, rkp. OE HAZU NZ 124b, 98 str.

Čakalić, Ivo (1905-1956), Bilježnica starina II, rkp. OE HAZU NZ 124c, 73 str.

Čakalić, Ivo (1963), Opis starina, rkp. OE HAZU NZ 124d, 118 str.

Čakalić, Ivo (1905-1956), Stare pisme i pismice, rkp. OE HAZU NZ 124e, 72 str.

Čakalić, Ivo (1905-1956), Starine, radovi i običaji, čudesa i svetišta i pričice, rkp. OE HAZU NZ 124f, 503 str.

Čakalić, Ivo (1905-1956), Spomenica župe Kaptol, rkp. OE HAZU NZ 124g, 90 str.

Čakalić, Ivo (1905-1956), Starine u našem kraju, rkp. OE HAZU NZ 124h, 194 str.

Čakalić, Ivo (1920-1968), Duhovne pisme od Blažene Divice Marie i druge pismice, rkp.

OE HAZU NZ 124i, 524 str. 
Čakalić, Ivo (1959), Svatovski običaji u starini, rkp. OE HAZU NZ 124j, 66 str.

Čakalić, Ivo (1905-1956), Male pričice, rkp. OE HAZU NZ 124k, 87 str.

Čakalić, Ivo (1905-1956), Pisme složene iz legendah i iz pripovidanja od starih, rkp. OE HAZU NZ 1241, 244 str.

Čakalić, Ivo (1905-1956), Pisme iz čitanja i pripovidanja, rkp. OE HAZU NZ 124m, 477 str. Čakalić, Ivo (1967), Voćinska processia, rkp. OE HAZU NZ 124n, 16 str.

Čakalić, Ivo (1940), Dila alkohola, rkp. OE HAZU NZ 124o, 18 str.

Čakalić, Ivo (1955), Pjesma Dragutin i Katica, rkp. OE HAZU NZ 124p, 47 str.

Čakalić, Ivo (1905-1956), Varia (ostavština, etnografska građa), rkp. OE HAZU NZ $124 r, 192$ str.

Čakalić, Ivo (oko 1960), Odgovori na pitanja o zadruzi, rkp. OE HAZU NZ 124s, 14 str. Čakalić, Ivo (1966-1972), Korespondencija, rkp. OE HAZU NZ 124š.

Ljetopis Jugoslavenske akademije znanosti i umjetnosti (od 1992. Ljetopis Hrvatske akademije znanosti i umjetnosti); svesci: 4/1889., 10/1896., 11/1897., Zagreb: Dionička tiskara. Dostupno i na internetskoj stranici Akademijina Digitalnog repozitorija: https://dizbi.hazu.hr

Marković, Mirko (1977), Akademik Vinko Žganec [Nekrolog.]. Zbornik za narodni život i običaje (47) [ur. A. Mohorovičić i M. Marković], str. 359-361.

Mihanović, Nedjeljko i Julije Njikoš (1983), Josip Andrić. Hrvatski biografski leksikon LZMK on-line (http://hbl.lzmk.hr/clanak.aspx?id=582).

Petrović-Leš, Tihana (2017), In memoriam Zdenka Lechner (1918.-2017.). Etnološka tribina 47(40), str. 321-322.

Maretić, Tomo (1895), Poziv za folkloristički zbornik. JAZU: Dionička tiskara u Zagrebu.

Marković, Franjo (1897), Izvještaj tajnika o književnom radu akademije g. 1896. Svečana sjednica od 22 .prosinca 1896. U: Ljetopis 11, str. 86.

Primorac, Jakša (2010), Arhivska građa Odsjeka za etnologiju HAZU. U: K. Batina et alt (prir.), Dokumentacijski pregled arhivskog gradiva Odsjeka za etnologiju Hrvatske akademije znanosti i umjetnosti. Zbornik za narodni život i običaje (knj. 55). Zagreb: HAZU, str. 9-37.

Rački, Franjo (1889), Svečano slovo predstojnika dra. Fr. Račkoga. Izvještaj sa svečane sjednice od 13. siječnja 1889. U: Ljetopis 4, str. 76-109.

Radić, Antun (1897), Osnova za sabirańe i proučavańe građe o narodnom životu. U: A. Radić (ur.), Zbornik za narodni život i običaje 2. Zagreb: HAZU, str. 1-90.

Vrbanić, Fran (1896), Izvještaj tajnika. Glavna skupština od 16. prosinca 1895. U: Ljetopis 10, str. 79.

Zečević, Divna (1993), Čakalić, Ivo. Natuknica u: Hrvatski biografski leksikon (LZMK) Online izdanje: http://hbl.lzmk.hr/clanak.aspx?id=3909 


\section{Prilozi}

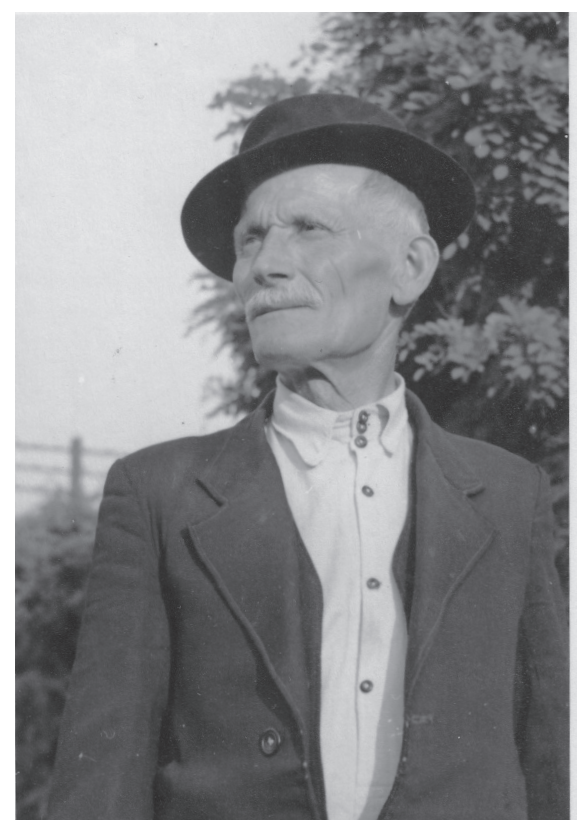

Slika 1. Ivo Čakalić. 1952/3. Zbirka fotografija Odsjeka za etnologiju HAZU (sign. F.45).

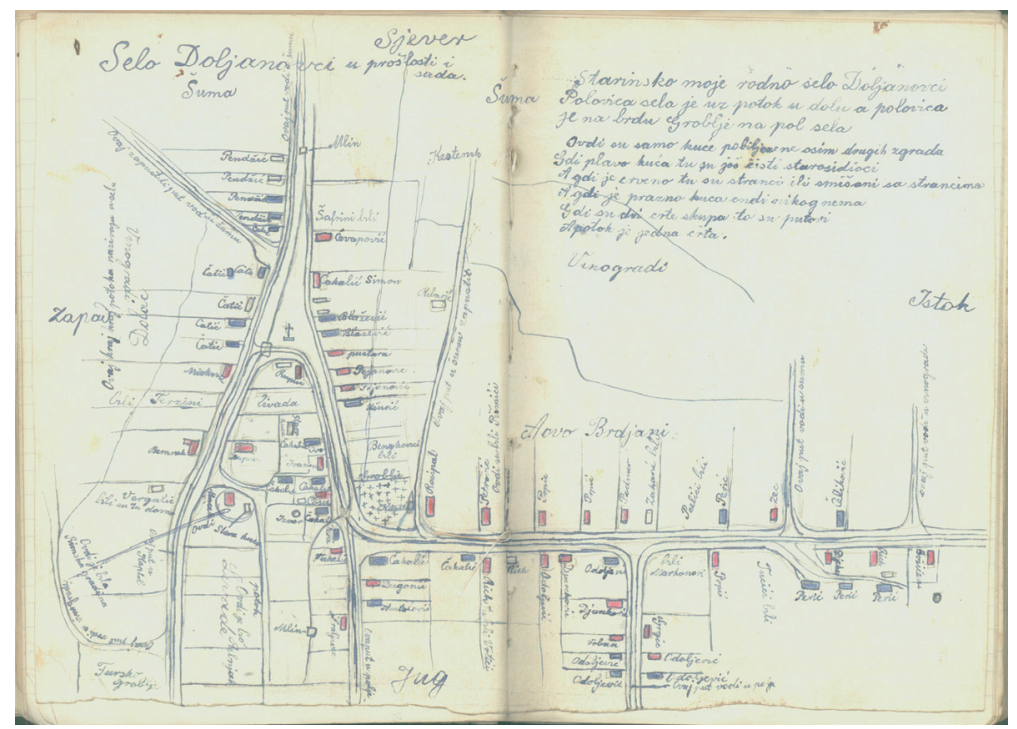

Slika 2. Crtež Selo Doljanovci u prošlosti i sada (rkp. Starine u našem kraju). Autor: Ivo Čakalić, oko 1950. Nova zbirka Odsjeka za etnologiju HAZU (sign. NZ 124h). 


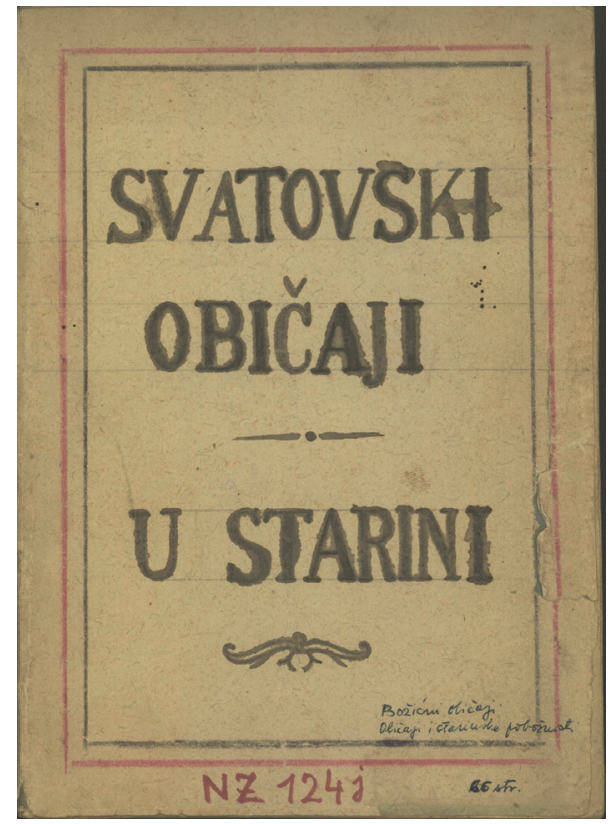

Slika 3. Naslovnica rukopisa Svatovski običaji u starini. Autor: Ivo Čakalić, 1959. Nova zbirka Odsjeka za etnologiju HAZU (sign. NZ 124j).

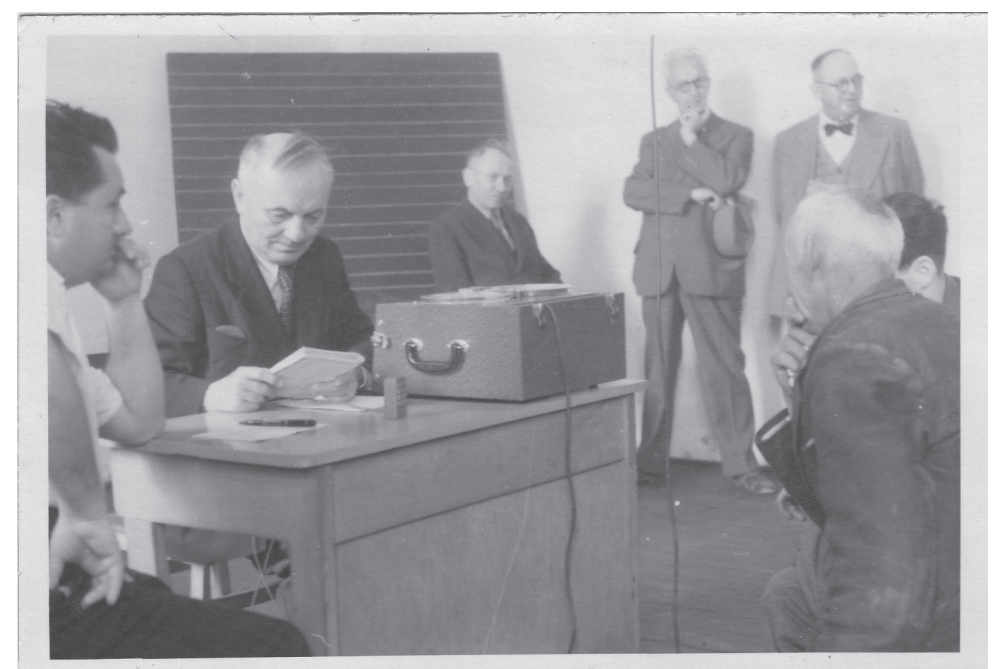

Slika 4. Melografsko snimanje u Pleternici. 1952/3. Zbirka fotografija Odsjeka za etnologiju HAZU (sign. F.45). 


\section{Cooperation between Folk Ethnographer Ivo Čakalić and the Committee for Folk Life and Customs}

\section{Summary}

The paper analyses the content and the importance of ethnographic and folklorist writings by the Croatian folk poet and ethnographer Ivo Čakalić (1889-1971), born in Doljanovci near Požega, in the context of his cooperation with Vinko Žganec and the Institute of Ethnology of the Croatian Academy of Sciences and Arts. Though not academically educated, Ivo Čakalić was a keen reader and writer. He dedicated a major part of his life to recording old folk customs, sayings and folk songs thematizing miracles and events both from the lives of saints and from everyday life. Since he collaborated with many experts and intellectuals of his time, who encouraged him to record ethnographic and folklorist material, the most of his writings remained preserved. The handwritten legacy of Ivo Čakalić is presently in custody of several institutions in Zagreb, Požega, Osijek and Kaptol, as well as in private collections. The archives of the Division of Ethnology currently house twenty-one collection of manuscripts, mainly thanks to ethnomusicologist Vinko Žganec. The correspondence and the photographs taken by Žganec during field research conducted in Požega and its surroundings witness to the course of this collaboration. The fact that all of Čakalić's writings have been digitized and published in the Academy's digital repository serves as proof of their value and relevance.

Keywords: Ivo Čakalić; Doljanovci; ethnographic writings; writings related to oral literature; Vinko Žganec; Institute of Ethnology of the Croatian Academy of Sciences and Arts.

Dr. sc. Klementina Batina, stručna savjetnica

Odsjek za etnologiju Hrvatske akademije znanosti i umjetnosti

Hebrangova 1, 10000 Zagreb

klementina@hazu.hr 